\title{
SYNTHESIS, CHARACTERIZATION AND CYTOTOXICITY EVALUATION OF Ni(II), Cu(II) AND Zn(II) COMPLEXES WITH DEOXYCHOLATE LIGAND
}

\author{
DANIELA C. CULITA $^{1 \# *}$, LORA DYAKOVA ${ }^{2 \#}$, GABRIELA MARINESCU ${ }^{1}$, TANYA ZHIVKOVA ${ }^{3}$, \\ MILENA GEORGIEVA ${ }^{4}$, BELA VASILEVA ${ }^{4}$, ROSSEN SPASOV ${ }^{5}$, GEORGE MILOSHEV $^{4}$, \\ RENI KALFIN $^{2}$, MELITA VIDAKOVIC ${ }^{6}$, OVIDIU OPREA ${ }^{7}$, RADOSTINA ALEXANDROVA $^{3}$ \\ 1 "Ilie Murgulescu” Institute of Physical Chemistry, Romanian Academy, Bucharest, Romania \\ ${ }^{2}$ Institute of Neurobiology, Bulgarian Academy of Sciences, Sofia, Bulgaria \\ ${ }^{3}$ Institute of Experimental Morphology, Pathology and Anthropology with Museum, Bulgarian Academy of Sciences, Sofia, \\ Bulgaria \\ 4 "Acad. Roumen Tsanev" Institute of Molecular Biology, Bulgarian Academy of Sciences, Sofia, Bulgaria \\ ${ }^{5}$ Faculty of Medicine, "St. Kliment Ohridski” Sofia University, Sofia, Bulgaria \\ ${ }^{6}$ Institute for Biological Research, Belgrade, Serbia \\ ${ }^{7}$ Politehnica University of Bucharest, Faculty of Applied Chemistry and Materials Science, Bucharest, Romania
}

*corresponding author: danaculita@yahoo.co.uk

${ }^{\#}$ Authors with equal contribution.

Manuscript received: June 2020

\begin{abstract}
Three new complexes of $\mathrm{Ni}(\mathrm{II}), \mathrm{Cu}(\mathrm{II})$ and $\mathrm{Zn}$ (II) with deoxycholate anion, of the type $\mathrm{M}(\mathrm{DCA})_{2} \cdot \mathrm{nH}_{2} \mathrm{O}(\mathrm{M}=\mathrm{Cu}(\mathrm{II}) \mathrm{n}=4$, $\mathrm{M}=\mathrm{Ni}(\mathrm{II}) \mathrm{n}=3$ and $\mathrm{M}=\mathrm{Zn}(\mathrm{II}) \mathrm{n}=2$ ) have been synthesized and characterized on the basis of elemental analysis, FTIR and UV-Vis spectroscopy, thermal analysis, molar conductivity and magnetic measurements. The cytotoxicity of the synthesized complexes was tested against HT29 human colorectal cancer cells. Applied at a concentration range of $10-200 \mu \mathrm{g} / \mathrm{mL}$, sodium deoxycholate and its metal complexes have been found to decrease viability and growth of cultured HT29 cells in a time- and concentration-dependent manner in short-term and long-term experiments. The ability of the complexes to induce pathological changes, genotoxicity and apoptosis in the treated cells has also been proved. In addition, the complexes demonstrated a cytotoxic effect in HT29-OxPt (resistant to oxaliplatin) cells, allowing to conclude that they are more pronounced cytotoxic agents as compared to the sodium deoxycholate alone.
\end{abstract}

\section{Rezumat}

Trei noi complecși ai $\mathrm{Ni}(\mathrm{II}), \mathrm{Cu}(\mathrm{II})$ și $\mathrm{Zn}$ (II) cu anionul deoxicolat, de tipul $\mathrm{M}(\mathrm{DCA})_{2} \cdot \mathrm{nH}_{2} \mathrm{O}(\mathrm{M}=\mathrm{Cu}$ (II) $\mathrm{n}=4, \mathrm{M}=\mathrm{Ni}(\mathrm{II}) \mathrm{n}=3$ și $\mathrm{M}=\mathrm{Zn}(\mathrm{II}) \mathrm{n}=2$ ), au fost sintetizați și caracterizați pe baza analizei elementale, a spectroscopiei FTIR și UV-Vis, analizei termice, conductivității molare și a măsurătorilor magnetice. Citotoxicitatea complecșilor sintetizați a fost testată pe celule canceroase colorectale umane HT29. La concentrații de $10-200 \mu \mathrm{g} / \mathrm{mL}$, s-a observat că deoxicolatul de sodiu şi complecşii săi metalici scad viabilitatea și dezvoltarea celulelor colorectale umane HT29 cultivate, într-o manieră dependentă de timp și concentrație, în experimente pe termen scurt şi pe termen lung. Capacitatea complecşilor de a induce modificări patologice, genotoxicitate și apoptoză în celulele tratate a fost de asemenea dovedită. În plus, complecşii au demonstrat un efect citotoxic asupra celulelor HT29-OxPt (rezistente la oxaliplatină), permițându-ne să concluzionăm că sunt agenți citotoxici mai puternici comparativ cu deoxicolatul de sodiu.

Keywords: deoxycholate complexes, transition metals, cytotoxicity, colorectal cancer cells

\section{Introduction}

It is well-known that metals accumulated in the liver cause serious problems. The use of chelating agents which facilitate urinary excretion may be a solution of these problems, but it has the disadvantage that kidneys damage could occur. An alternative way for excretion of such metals via bile and faeces could be the use of bile acids and its derivatives as chelating agents. Progress in understanding how bile salts interact with metal ions in solution depends on the knowledge of their coordination with metal ions [1-3].
Bile acids are steroid compounds usually containing one to three hydroxyl groups linked to a steroid nucleus and a short aliphatic side chain having a carboxyl group at the end [4]. Primary bile acids, including cholic and chenodeoxycholic acid are synthesized in the liver and constitute the main components of bile [5]. In the colon, intestinal microflora transforms primary bile acids into secondary bile acids, such deoxycholic, lithocholic and ursodeoxycholic acids [6]. The main roles of bile acids in the organism are solubilisation and adsorption of lipids, cholesterol and lipid-soluble 
vitamins [6]. They also exhibit a broad spectrum of biological activities such as antimicrobial, anticancer, antiinflamatory, antifungal, etc. [4]. A significant number of published papers reports various chemical transformations of the bile acids including etherification, amidation [7, 8], esterification [9], replacement of hydroxyl with keto groups [10], etc. aiming to enhance their biological activities. In the last years, bile acids became important as drug vehicles for delivering platinum-related cytostatic drugs to the liver $[11,12]$ and also to modify the solubility of drugs [13]. Such kind of compounds containing transition metals (platinum, gold and palladium) and bile acids, designated as Bamet, were synthesized and characterized, and proved to have cytostatic and anti-tumour properties [14-16]. Bamet-UD2 is a cisplatin-ursodeoxycholate derivative with strong antitumour activity, marked hepatobiliary organotropism and reduced toxic side effects as compared to the parent drug cisplatin [17]. Bamet$\mathrm{R} 2$, a complex of cisplatin with glycocholate, is a strong cytostatic and antitumour compound, probably due to its ability to modify DNA structure and to inhibit DNA synthesis [9].

The need to find a safe and highly selective cure for neoplastic diseases remains a major challenge for modern science. The discovery of the antitumour efficacy of cisplatin and some related platinum compounds (carboplatin, oxaliplatin) has stimulated the search for other metal complexes with antineoplastic properties. Various metal complexes, including zinc, copper and cobalt, are found to be promising substances for the design of new anticancer agents [18-21].

The goal of this research was to extend the range of coordination compounds of transition metals with bile acids and to evaluate their cytotoxic activity against HT29 human colorectal cells and HT29-OxPt (resistant to oxaliplatin) cells. Therefore, we decided to study the coordination compounds of $\mathrm{Cu}$ (II), $\mathrm{Ni}$ (II) and $\mathrm{Zn}$ (II) with the anion of deoxycholic acid, one of the most important secondary bile acids. It is well known that in the human body deoxycholic acid takes part in the emulsification of fats for the absorption in the intestine [22]. Outside the body it is used in experimental basis of cholagogues. Currently, it is part of predominantly gallstone reducing medicines (choleretics). Recently, deoxycholic acid has been approved as a food additive in some countries. Newer approaches are assumed that deoxycholic acid plays an important role in the immune system, possibly as an activator of macrophages in tumour tissue and in inflammation. Sodium deoxycholate (NaDCA), the sodium salt of deoxycholic acid, is frequently used in mesotherapy injections, mixed with phosphatidyl choline. Also, it is often used as a biological detergent to lyse cells and solubilize cellular and membrane components [23]. Some papers on the capacity of different bile acids to coordinate metal ions have also been published [3, 24-28].

\section{Materials and Methods}

Deoxycholic acid sodium salt (Calbiochem, Germany), nickel nitrate hexahydrate $\left(\mathrm{Ni}\left(\mathrm{NO}_{3}\right)_{2} \cdot 6 \mathrm{H}_{2} \mathrm{O}\right)$, copper nitrate trihydrate $\left(\mathrm{Cu}\left(\mathrm{NO}_{3}\right)_{2} \cdot 3 \mathrm{H}_{2} \mathrm{O}\right)$, zinc nitrate hexahydrate $\left(\mathrm{Zn}\left(\mathrm{NO}_{3}\right)_{2} \cdot 6 \mathrm{H}_{2} \mathrm{O}\right)$ (Merck, Germany) were of analytical grade. The other materials Dulbecco's modified Eagle's medium (DMEM) and foetal bovine serum (FBS) were purchased from Gibco-Invitrogen (UK). Dimethyl sulfoxide (DMSO), neutral red, crystal violet and trypsin were obtained from AppliChem (Germany), thiazolyl blue tetrazolium bromide (MTT), purified agar and consumables for the Comet Assay were from Sigma Aldrich Chemie GmbH (Germany). All other chemicals of the highest purity commercially available were purchased from local agents and distributors. All sterile plastic and syringe filters were from Orange Scientific (Belgium). The fluorescent dye SYBR ${ }^{\circledR}$ Green I for fluorescent visualization of Comet Assay results was purchased from SigmaAldrich (S9430). Annexin V/FITC Apoptosis/Necrosis detection kit was purchased from ENZO (ALX-850020-KI02).

\section{Synthesis of the complexes}

Stoichiometric amounts of metal salt and sodium deoxycholate were dissolved separately in water, at room temperature. The metal complexes were obtained as fine precipitates by adding sodium deoxycholate solution into the metal salt solution drop by drop, under stirring, at $50^{\circ} \mathrm{C}$. After 60 minutes, the precipitates were filtered, washed several times with distilled water and dried in desiccator over $\mathrm{P}_{4} \mathrm{O}_{10}$.

Methods

All solid complexes obtained were characterized by elemental chemical analysis, FTIR and UV-Vis spectroscopy, thermal analysis, magnetic and conductivity measurements. The results are presented in Table I.

The FTIR spectra were recorded on $\mathrm{KBr}$ pellets in the wavenumber region $4000-400 \mathrm{~cm}^{-1}$ using a Jasco FTIR-4700 spectrometer.

Table I

Elemental chemical analysis and physical properties of the compounds

\begin{tabular}{|c|c|c|c|c|c|c|c|}
\hline \multirow[t]{2}{*}{ Compound } & \multirow[t]{2}{*}{ Colour } & \multirow{2}{*}{$\begin{array}{c}\text { Molecular } \\
\text { weight }\end{array}$} & \multirow[t]{2}{*}{ Yield \% } & \multicolumn{2}{|c|}{ Found/calcd. (\%) } & \multirow{2}{*}{$\begin{array}{c}\mu_{\text {eff }} \\
(\mathbf{B M})\end{array}$} & \multirow{2}{*}{$\begin{array}{l}\text { Molar conductivity } \\
(\mu \mathrm{S} / \mathrm{cm})\end{array}$} \\
\hline & & & & $\mathrm{C}$ & $\mathrm{H}$ & & \\
\hline CuDCA & Olive green & 918.5 & 76 & $62.87 / 62.69$ & $9.21 / 9.36$ & 1.71 & 1.8 \\
\hline NiDCA & Light green & 895.7 & 73 & $63.76 / 64.29$ & $9.20 / 9.37$ & 3.31 & 3.0 \\
\hline $\mathrm{ZnDCA}$ & White & 884.4 & 79 & $64.06 / 65.11$ & $9.23 / 9.26$ & Diamagnetic & 1.8 \\
\hline
\end{tabular}

$\mathrm{CuDCA}=\mathrm{Cu}(\text { DCA })_{2} \cdot 4 \mathrm{H}_{2} \mathrm{O} ; \mathrm{NiDCA}=\mathrm{Ni}(\text { DCA })_{2} \cdot 3 \mathrm{H}_{2} \mathrm{O} ; \mathrm{ZnDCA}=\mathrm{Zn}(\text { DCA })_{2} \cdot 2 \mathrm{H}_{2} \mathrm{O}$ 
FARMACIA, 2021, Vol. 69, 3

The electronic spectra were recorded on a Jasco V-750 spectrophotometer equipped with diffuse reflectance accessories. Magnetic measurements were performed by Faraday method with Mohr salt as a standard, at room temperature. Elemental analysis was performed on a Perkin Elmer CHNS/O Analyzer 2400 Series II. Thermal analysis (TG/DSC) of the compounds was performed with a Netzsch TG 449C STA Jupiter thermal analyser at a heating rate of $10^{\circ} \mathrm{C} / \mathrm{min}$, from room temperature to $900^{\circ} \mathrm{C}$, in air. Molar conductivity of $10^{-3} \mathrm{M}$ solutions in DMSO was measured at $17^{\circ} \mathrm{C}$, on a Mettler Toledo SevenGo Duo SG23 conductivity meter.

\section{Cell model systems and cultivation}

The compounds were dissolved in dimethyl sulfoxide (the concentration of the compound in the stock solution was $1 \mathrm{mg} / \mathrm{mL}$ containing 2\% DMSO) and then diluted in culture medium. The stability of the complexes dissolved in DMSO was checked by recording their UV-Vis spectra for a week, once every two days. No differences were observed between the spectra, which proved that the complexes in DMSO solution are stable over time.

Human permanent cell line HT29 established from a colorectal adenocarcinoma as well as its resistant to Oxaliplatin clone HT29-OxPt [29] were used as model systems in our study. The cells were grown in D-MEM medium supplemented with 5 - $10 \%$ foetal bovine serum, $100 \mathrm{U} / \mathrm{mL}$ penicillin and $100 \mu \mathrm{g} / \mathrm{mL}$ streptomycin. The cell cultures were kept in a humidified incubator (Thermo Scientific, HEPA Class 100 ) at $37^{\circ} \mathrm{C}$ under $5 \% \mathrm{CO}_{2}$ in air. For routine passages the cells were detached using a mixture of $0.05 \%$ trypsin and $0.02 \%$ EDTA. The cell lines were passaged 2 - 3 times per week (1:2 to 1:3 split). The lower sensitivity of HT29-OxPt cells to the cytotoxic effect of oxaliplatin was proved using MTT test $-\mathrm{CC}_{50}$ calculated after $72 \mathrm{~h}$ of treatment was found to be 60.5 $\mu \mathrm{M}$ for HT29 cell and $241.1 \mu \mathrm{M}$ for HT29-OxPt cells. Prior to subsequent experiments, the HT29OxPt cells were maintained in drug-free growth medium for at least one week [29].

Cytotoxicity assays

The cells were seeded in 96-well flat-bottomed microplates at a concentration of $1 \times 10^{4}$ cells/well. At the $24^{\text {th }}$ hour, the culture medium was removed and changed with media containing different concentrations of the compounds tested (10, 50, 100 and $200 \mu \mathrm{g} / \mathrm{mL})$. Each concentration was applied in 6 to 8 wells. Samples of cells grown in non-modified medium served as a control. The effect of the compounds on cell viability and proliferation was evaluated using thiazolyl blue tetrazolium bromide (MTT) test, neutral red uptake cytotoxicity assay (NR assay) and crystal violet staining (CV staining) after $24-72 \mathrm{~h}$ of incubation. The MTT assay of cell viability was performed in accordance with the the Mossmann's procedure [30]. The cells were incubated for $3 \mathrm{~h}$ with MTT solution (5 $\mathrm{mg}$ MTT in $10 \mathrm{~mL} \mathrm{D-MEM)} \mathrm{at} 37^{\circ} \mathrm{C}$ under $5 \%$ carbon dioxide in the air. The formed blue MTT formazan was extracted with a mixture of absolute ethanol and DMSO (1:1, vol/vol).

The neutral red (NR) cytotoxicity assay was based on the method of Borenfreund and Puerner [31]. A solution of $\mathrm{NR}(50 \mu \mathrm{g} / \mathrm{mL}, 0.1 \mathrm{~mL})$ was added to each well containing cells. The plates were placed in $\mathrm{CO}_{2}$ incubator for $3 \mathrm{~h}$ to ensure the uptake of vital dye. Next, the NR-containing medium was removed and the cells were washed with phosphate-buffered saline (PBS, pH 7.2; $0.2 \mathrm{~mL} /$ well). The addition of $0.1 \mathrm{~mL}$ $1 \%$ acetic acid solution containing $50 \%$ ethanol extracts the dye from the viable cells.

Crystal violet staining was performed as described by Saotome et al. [32]. The microplate with tested compounds was incubated for $72 \mathrm{~h}$ at $37^{\circ} \mathrm{C}$ in $5 \%$ $\mathrm{CO}_{2}$ atmosphere. After this period, the medium was removed and the cells were stained with $0.4 \%$ crystal violet solution in methanol for $30 \mathrm{~min}$ and carefully washed with distilled water.

The final step of cytotoxicity assays - quantitative analysis, was performed by absorbance measurements in an automatic microplate reader (TECAN, Sunrise ${ }^{\mathrm{TM}}$, Austria) at 540/620 nm (for MTT test and CV staining) and $540 \mathrm{~nm}$ (for NR assay). Relative cell viability, expressed as a percentage of the control, was calculated for each concentration of sodium deoxycholate and its metal complexes. Concentration-response curves were prepared and the effective concentrations of the compounds $-\mathrm{CC}_{50}$ (that decrease by $50 \%$ the amount of viable cells as compared to the control) and/or $\mathrm{CC}_{90}$ (causing a $90 \%$ reduction of cell viability as compared to the control) were estimated where possible. All data points represent an average of at least three independent assays.

Double staining with acridine orange and propidium iodide

The ability of compounds to induce cytopathological changes was evaluated using double staining with acridine orange (AO) and propidium iodide (PI) according to the standard procedures [33]. The cells were cultured on cover slips in 6-well plates in the presence of the compounds tested. Non-treated cells served as a control. After $48 \mathrm{~h}$ of incubation, the coverslips were removed and washed with phosphate buffered saline (PBS) for $2 \mathrm{~min}$. A mixture, containing equal volumes (1:1) of fluorescent dyes AO $(10 \mu \mathrm{g} / \mathrm{mL}$ in PBS) and PI (10 $\mu \mathrm{g} / \mathrm{mL}$ in bi-distilled water) were added to the cells. Fresh stained cells were placed on a glass slide and examined under fluorescence microscope (Leika DM 500B, Wetzlar, Germany) within 30 min before the fluorescent colour started to fade. Single cell gel electrophoresis (Comet assay) The alkaline variant of the Comet assay, designed by Olive et al. [34], was used in the current research with minor modifications [35]. Gels were prepared by mixing the cells with $1.4 \%$ low-gelling agarose. The 
cell-agarose suspension was spread onto microscopic slides followed by lysis of cells in a cold lysis solution (1 M NaCl, 50 mM EDTA pH 8, 30 mM NaOH, 0.1\% $\mathrm{N}$-lauroyl sarcozine; $\mathrm{pH} 10$ ) for 1 hour at $10^{\circ} \mathrm{C}$. DNA was denatured by incubating the slides $3 \times 20 \mathrm{~min}$ in a denaturing solution $(30 \mathrm{mM} \mathrm{NaOH}, 10 \mathrm{mM}$ EDTA; $\mathrm{pH}$ 12.6). Electrophoresis was conducted at $10^{\circ} \mathrm{C}$ for 20 minutes, at $0.45 \mathrm{~V} / \mathrm{cm}$ in the same denaturing solution. The slides were washed with $0.5 \mathrm{M}$ Tris- $\mathrm{HCl}$, pH 7.5 to neutralize the alkali and were dehydrated by successive washes in $75 \%$ and $95 \%$ ethanol for 5 min each. Comets were observed under a Leitzepifluorescence microscope (Orthoplan, Vario Orthomat 2) using 450 - $490 \mathrm{~nm}$ band-pass filter following staining of DNA with SYBR green I. Pictures were taken with a digital photo camera, Olympus $\mu 8$, at a resolution of $3 \mathrm{Mpx}$. Quantification of results was conducted by calculating the percentage of comets in each sample.

\section{Identification of cell death}

Apoptosis detection was performed using Annexin V-FITC Certified Apoptosis/Necrosis detection kit as it was recommended by the manufacturer (ENZO, Romania). Briefly, cells were spun down at $400 \mathrm{~g}$ for $5 \mathrm{~min}$ at room temperature and were carefully resuspended in $1 \mathrm{~mL}$ cold $1 \mathrm{x}$ PBS $(2.68 \mathrm{mM} \mathrm{KCl}$, $1.47 \mathrm{mM} \mathrm{KH}_{2} \mathrm{PO}_{4}, 1.37 \mathrm{mM} \mathrm{NaCl}, 8 \mathrm{mM} \mathrm{Na}_{2} \mathrm{HPO}_{4}$ ), $\mathrm{pH}$ 7. Spinning down follows at the same conditions and the pellet was resuspended in $510 \mu \mathrm{L}$ Dual Detection Reagent $(500 \mu \mathrm{L} 1 \mathrm{x}$ binding buffer, $5 \mu \mathrm{L}$ Apoptosis Detection reagent/Annexin V-Enzo Gold; $5 \mu \mathrm{L}$ Necrosis Detection Reagent). Samples were incubated at room temperature for $10 \mathrm{~min}$ at dark and were analysed via cytometry using $488 \mathrm{~nm}$ laser at FL 2 and FL 3 channels for apoptosis and necrosis detection respectively. FACS analysis was performed on the model HT29 cells treated with the studied compounds at increasing concentrations. Cellular morphology was assessed and results are presented as four groups of cells with different cell size and granularity. Each value represents the percentage of cells with specific morphology as a percentage from the whole cell population. Results were quantified with FlowJo software. Population of live cells, and cells in early, late apoptosis and necrosis were calculated as a percentage of the whole cell population.

\section{D Colony forming method}

Tumour cells $\left(10^{3}\right.$ cells/well $)$ suspended in $0.45 \%$ purified agar in D-MEM medium containing different concentrations of deoxycholic acid and its metal complexes (concentrations of 10 to $200 \mu \mathrm{g} / \mathrm{mL}$ ) were layered in 24 well plates. Non-treated cells served as a control. The presence/absence of colonies and their number (counted in at least 4 - 5 different fields or each well) were registered using an inverted microscope
(Carl Zeiss, Jena, Germany) during a period of 48 days (counted on 3 - 5-day intervals).

Statistical analysis

The data are presented as mean \pm standard error of the mean. Statistical differences between control and treated groups were assessed using one-way analysis of variance (ANOVA) followed by Dunnett post-hoc test. Effective concentrations of the compounds $\mathrm{CC}_{50}$ and/or $\mathrm{CC}_{90}$ were estimated by Origin $6.1^{\mathrm{TM}}$. FACS data were quantified by FlowJo software. Comet Assay data were statistically evaluated using CometScore Software.

\section{Results and Discussion}

Physico-chemical characterization of the compounds The complexes $\mathrm{M}(\mathrm{DCA})_{2} \cdot \mathrm{n} \mathrm{H}_{2} \mathrm{O}(\mathrm{M}=\mathrm{Cu}(\mathrm{II}) \mathrm{n}=4$; $\mathrm{M}=\mathrm{Ni}(\mathrm{II}) \mathrm{n}=3$ and $\mathrm{M}=\mathrm{Zn}(\mathrm{II}) \mathrm{n}=2$ ) were prepared in high yields upon mixing aqueous solutions of metal salts and deoxycholic acid sodium salt, in a 1:2 molar ratio, at $50^{\circ} \mathrm{C}$. The compounds are soluble in warm DMSO and insoluble in water and most of the organic solvents. The molecular formulae of the complexes were established by correlating the elemental analysis results with thermal analysis, spectroscopic data, magnetic moments and conductivity values (Table I).

In order to obtain information about the coordination manner of the deoxycholate anion to the divalent transition metal ions, FTIR spectroscopic measurements were performed. The spectra of the complexes showed changes in the positions and intensities of some bands compared to those of the free ligand. The formation of the metal complexes was established by the presence of two strong bands in the following ranges: $1552-1598 \mathrm{~cm}^{-1}\left(v_{\text {asym(OCO) }}\right)$ and $1411-1417 \mathrm{~cm}^{-1}$ $\left(v_{\text {sym(OCO) }}\right)$ which are assigned to the coordinated carboxylate group (Table II). The bands corresponding to the asymmetrical and symmetrical vibrations of the $\mathrm{COO}^{-}$groups in complexes are slightly shifted as compared to sodium deoxycholate. The magnitude of separation $(\Delta v)$ between frequencies of asymmetrical and symmetrical vibrations of the $\mathrm{COO}^{-}$group is useful in defining the structure of complexes [36]. According to Shaheen [37], a $\Delta v$ value between 150 and $250 \mathrm{~cm}^{-1}$ suggests a bridging coordination, while $\Delta v$ below $150 \mathrm{~cm}^{-1}$ indicates a chelating mode of coordination. For the complexes of $\mathrm{Ni}$ (II) and $\mathrm{Zn}$ (II), $\Delta v$ is 142 and $141 \mathrm{~cm}^{-1}$ respectively, suggesting a bidentate chelate coordination mode. In the case of $\mathrm{Cu}$ (II) complex, two frequencies attributable to $v_{\text {asCOO }}$ were observed at 1598 and $1564 \mathrm{~cm}^{-1}$ indicating bidentate bridging and chelating coordination of the carboxylate groups to copper ion. The bands at $\sim 2935$ and $2864 \mathrm{~cm}^{-1}$ correspond to stretching vibrations of $\mathrm{C}-\mathrm{H}$ bonds, while the broad and intense band between $3000 \mathrm{~cm}^{-1}$ and $3600 \mathrm{~cm}^{-1}$ range in all spectra corresponds to $\mathrm{OH}$ stretching vibrations, formation 
FARMACIA, 2021, Vol. 69, 3

of hydrogen bond network and also confirms the presence of water molecules in complexes.

Table II

The characteristic frequency data of FTIR spectra for coordination compounds and their assignments

\begin{tabular}{ccccc}
\hline NiDCA & CuDCA & ZnDCA & NaDCA & Assignments \\
\hline 3385 & 3401 & 3357 & 3406 & $v \mathrm{OH}$ \\
2936 & 2936 & 2934 & 2935 & $v \mathrm{CH}$ \\
2866 & 2865 & 2864 & 2864 & $v \mathrm{CH}$ \\
& 1598, & 1552 & 1563 & $v_{\mathrm{as}} \mathrm{COO}^{-}$ \\
1555 & 1564 & & 1449 & $v \mathrm{CH}^{-}$ \\
1449 & 1449 & 1454 & 1407 & $v_{\mathrm{s}} \mathrm{COO}^{-}$ \\
1413 & 1417 & 1411 & 1407
\end{tabular}

The electronic absorption spectra are often very helpful in the evaluation of results furnished by other methods of structural investigation. The electronic spectral measurements were used to assign the stereochemistry of the metal ions in the complexes based on the positions and number of $d$ - $d$ transition peaks. The electronic absorption spectra of the ligand and its complexes were recorded in the $200-900 \mathrm{~nm}$ range, at room temperature.

The electronic spectrum of Ni(II) complex shows the characteristic features for (pseudo)octahedral Ni(II) complexes, with two bands at $555 \mathrm{~nm}$ and $1000 \mathrm{~nm}$ assigned to ${ }^{3} \mathrm{~A}_{2 \mathrm{~g}}(\mathrm{~F}) \rightarrow{ }^{3} \mathrm{~T}_{1 \mathrm{~g}}(\mathrm{~F})\left(\mathrm{v}_{2}\right)$ and ${ }^{3} \mathrm{~A}_{2 \mathrm{~g}}(\mathrm{~F}) \rightarrow$ ${ }^{3} \mathrm{~T}_{2 \mathrm{~g}}(\mathrm{~F})\left(v_{3}\right)$ transitions, respectively (Figure 1) [38, 39]. The shoulder at $\sim 350 \mathrm{~nm}$ could be assigned to the ${ }^{3} \mathrm{~A}_{2 \mathrm{~g}}(\mathrm{~F}) \rightarrow{ }^{3} \mathrm{~T}_{1 \mathrm{~g}}(\mathrm{P})\left(\mathrm{v}_{1}\right)$ transition of Ni(II). The effective magnetic moment of $3.31 \mathrm{BM}$ found for the $\mathrm{Ni}(\mathrm{II})$ complex suggests an octahedral arrangement around the metal ion [40].

The electronic spectrum of $\mathrm{Cu}(\mathrm{DCA})_{2} \cdot 4 \mathrm{H}_{2} \mathrm{O}$ presents an asymmetric band $(\sim 687 \mathrm{~nm})$ with a tail towards low energies, which is characteristic for square-pyramidal $\mathrm{Cu}$ (II) complexes (Figure 1) [38]. The $\mathrm{Cu}$ (II) complex shows a normal magnetic moment of $1.71 \mathrm{BM}$ observed for a d $d^{9}(S=1 / 2)$ system with an unpaired electron. The band located in the region $200-400 \mathrm{~nm}$ in the absorption spectra of all complexes is most probably due to a $\pi-\pi^{*}$ transition of the organic ligand. The $\mathrm{Zn}$ (II) complex shows no d-d bands as is expected for a $\mathrm{d}^{10}$ system. This compound was found to be diamagnetic.

Conductivity measurements reveal that all metal complexes have low conductivity values characteristic for non-electrolytic compounds [41, 42].

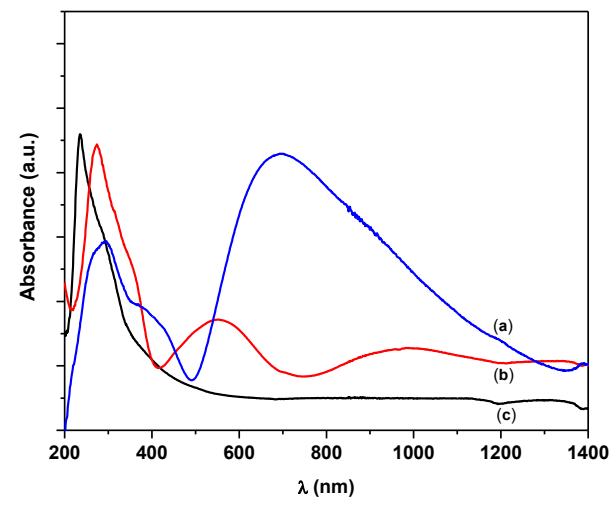

Figure 1.

UV-VIS spectra of (a) CuDCA, (b) NiDCA and (c) $\mathrm{ZnDCA}$

\section{Thermal analysis}

In order to give more insight into the structure of the complexes, thermal analyses (TG/DSC) have been carried out from room temperature up to $900^{\circ} \mathrm{C}$. The thermoanalytical curves are shown in Figure 2. The decomposition patterns are almost similar for all three complexes. From room temperature up to $170^{\circ} \mathrm{C}$ the mass loss ranging from 3.46 to $5.48 \%$ corresponds to endothermic release of water molecules (both crystallization and coordinated water). The weight loss recorded in the second step, between $170^{\circ} \mathrm{C}$ and $310^{\circ} \mathrm{C}$, could be most probably attributed to dehydroxilation of the organic ligand. In the next step occurring between $310^{\circ} \mathrm{C}$ and $450^{\circ} \mathrm{C}$ for $\mathrm{CuDCA}$, and the next two steps ranging from $310^{\circ} \mathrm{C}$ and $495^{\circ} \mathrm{C}$ for NiDCA and ZnDCA, all the three complexes undergo decomposition and oxidative degradation processes accompanied by overlapping exothermic effects. The fourth (for CuDCA) and the fifth (for NiDCA and ZnDCA) steps consist in complete pyrolysis of the remaining carbonaceous residue, the accompanying exothermic effects being very strong and broad. This step consists in transformation of the metallic intermediates into its stable oxides. The mass losses for each step are given in Table III.

Table III

Thermoanalytical data of the CuDCA, NiDCA and ZnDCA complexes

\begin{tabular}{cccc}
\hline Complex & Temperature range $\left({ }^{\circ} \mathbf{C}\right)$ & Thermal effect & Mass loss $(\Delta \mathbf{m}) \mathbf{( \% )}$ \\
\hline \multirow{4}{*}{ CuDCA } & $25-170$ & Endothermic & 3.46 \\
& $170-310$ & Endothermic & 5.60 \\
& $310-450$ & Exothermic & 46.48 \\
& $450-600$ & Exothermic & 35.16 \\
& Residue $\mathrm{CuO}$ & & 8.67 \\
NiDCA & $25-170$ & Endothermic & 5.48 \\
& $170-310$ & Endothermic & 1.56 \\
& $310-425$ & Exothermic & 59.59 \\
& $425-495$ & Exothermic & 8.26 \\
& $495-640$ & Exothermic & 17.18 \\
& Residue $\mathrm{NiO}$ & & 8.17
\end{tabular}


FARMACIA, 2021, Vol. 69, 3

\begin{tabular}{cccc}
\hline Complex & Temperature range $\left({ }^{\circ} \mathbf{C}\right)$ & Thermal effect & Mass loss $(\Delta \mathbf{m})(\mathbf{\%})$ \\
\hline \multirow{4}{*}{ ZnDCA } & $25-170$ & Endothermic & 3.88 \\
& $170-310$ & Endothermic & 1.75 \\
& $310-385$ & Exothermic & 11.64 \\
& $385-495$ & Exothermic & 59.20 \\
& $495-640$ & Exothermic & 14.64 \\
& Residue $\mathrm{ZnO}$ & & 8.53 \\
\hline
\end{tabular}

a

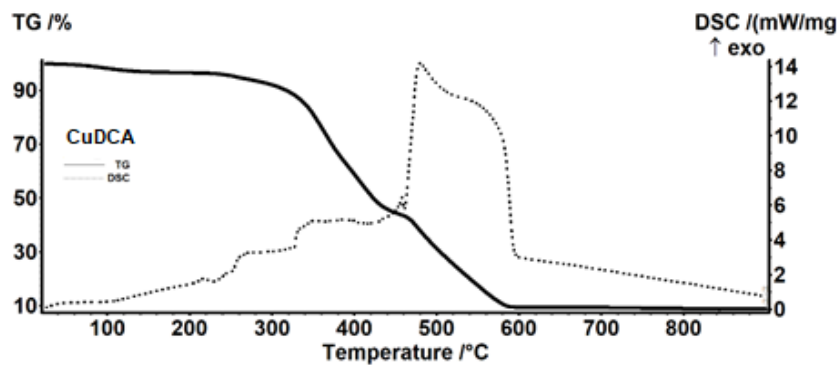

b
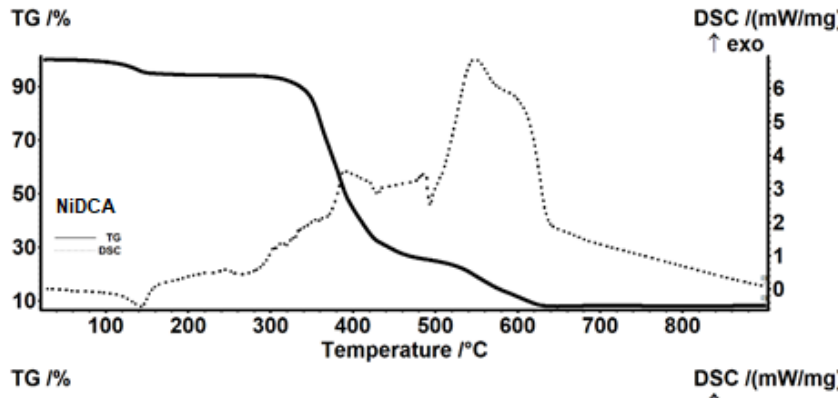

TG $1 \%$

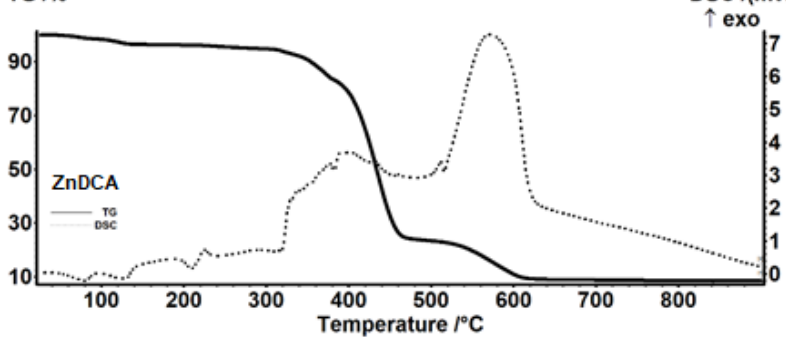

Figure 2.

TG/DSC curves for CuDCA (a), NiDCA (b) and ZnDCA (c)

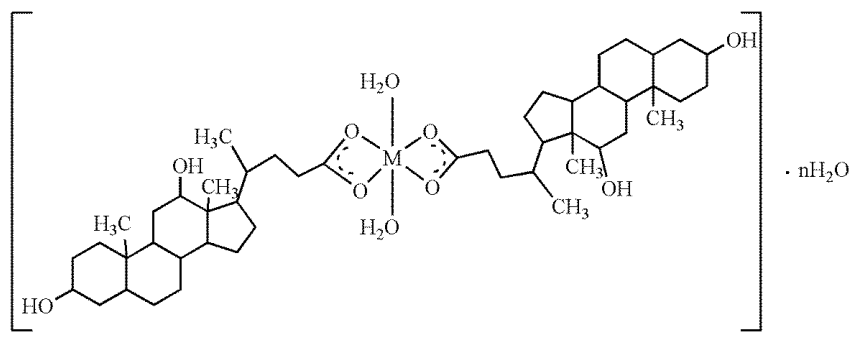

$\mathrm{M}(\mathrm{II}): \mathrm{Ni}(\mathrm{II}), \mathrm{n}=1 ; \mathrm{Zn}(\mathrm{II}), \mathrm{n}=0$

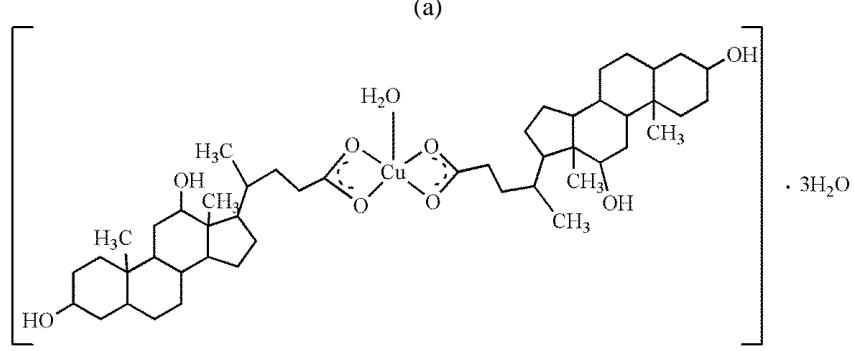

(b)

Figure 3.

Proposed structures of the complexes: a) NiDCA and ZnDCA; b) CuDCA 
Taking into account all the above data, the following structures of the complexes were proposed (Figure 3). Biological evaluation

Studying the antitumour activity of a new compound requires conduction of various experiments at different levels: subcellular/molecular, cellular (cell cultures) and organismic (animal models). Demonstrating the ability of a test substance to exert a cytotoxic effect in cell cultures used as model systems is the first, but not the last step. For example, it is necessary to study the cytotoxic effect of the substance on a wide range of cell cultures: derived from different malignancies, from different subtypes of the same tumour, including cell lines of the same subtype (this is due to the heterogeneity of tumour cells, which turns each tumour/ tumour cell line into an unique system); to identify the type of cell death caused by them (apoptosis, necrosis) and their ability to induce autophagy; to determine their targets and the mechanism of their action. A comparative analysis with non-tumour cells is needed, as well as comparison with the action of antitumour drugs established in clinical practice. In this regard, the presented results are part of a comprehensive study on the cytotoxic and antitumour properties of sodium deoxycholate and its metal complexes, which includes a wide range of cell cultures (human and animal tumour and non-tumour cells). For comparative analysis, antitumour drugs widely used in clinical oncology, such as cisplatin, oxaliplatin, epirubicin and paclitaxel, were included.

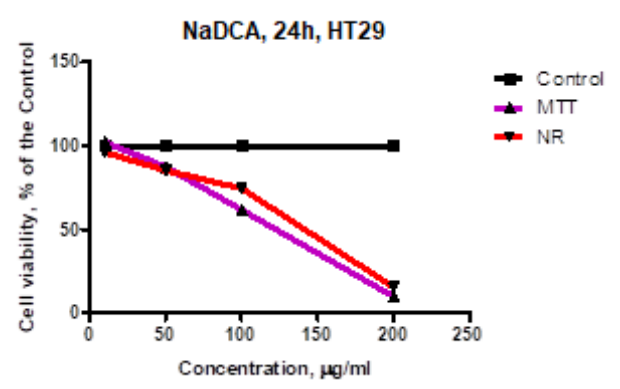

(a)

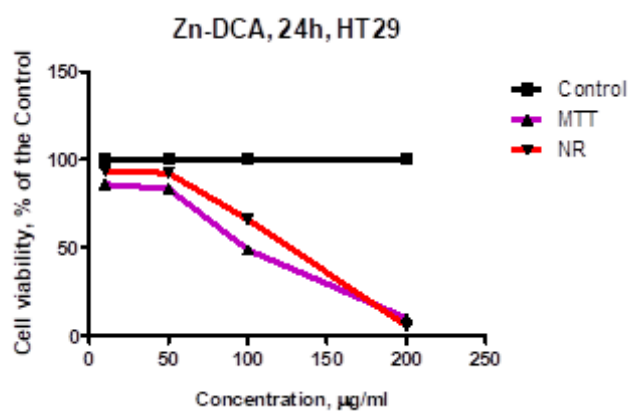

(b)
The cytotoxic activity of deoxycholic acid sodium salt and its metal complexes was evaluated using the MTT test which measures the ability of the mitochondrial enzyme succinate dehydrogenase to convert MTT into formazan, NR assay which provides information about the incorporation of neutral red into the lysosomes of living cells, staining of DNA and nuclear proteins with crystal violet, Comet Assay for evaluation of genotoxicity and FACS analysis for quantitation of the type of induced cell death [43, 44].

Applied at a concentration range of $10-200 \mu \mathrm{g} / \mathrm{mL}$ for $24-72 \mathrm{~h}$, the studied compounds decreased the viability and proliferation of the treated cells. Their cytotoxic activity was increased by increasing the concentrations and prolonging the treatment (Figures 4, 5 and 6). NaDCA and its metal complexes were found to decrease viability and growth of both HT29 (sensitive/ parental) and HT29-OxPt (resistant) human colorectal cancer cells (Figure 7).

The cytotoxic activity of DMSO alone has been studied in our previous investigations [45-47] in a wide variety of human and animal tumour and non-tumour cells, including HT29. It has been found that DMSO did not disturb significantly the viability and proliferation of the treated cells applied for $72 \mathrm{~h}$ at concentrations up to $0.8-1 \%$. In this study, NaDCA and its metal complexes were applied in concentrations from 1 to $200 \mu \mathrm{g} / \mathrm{mL}$, in which the content of DMSO was from 0.02 to $0.4 \%$, respectively, and its cytotoxic effect is negligible.

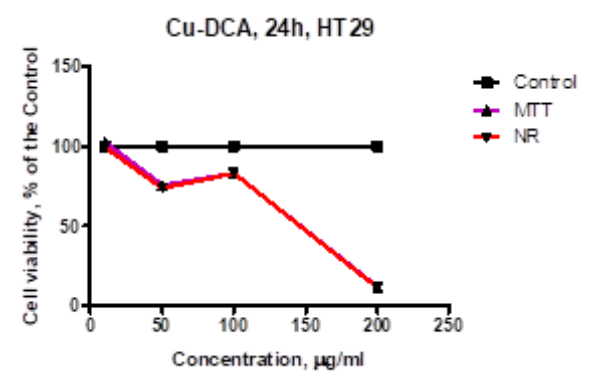

(c)

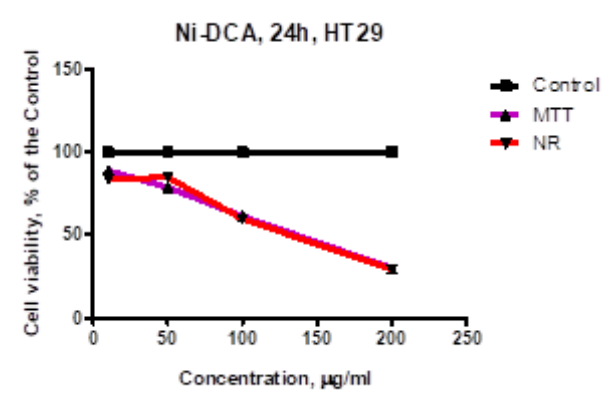

(d)

Figure 4.

Influence of NaDCA (a), ZnDCA (b), CuDCA (c) and NiDCA (d) complexes on viability and proliferation of cultured HT29 human colorectal cells

The compounds are applied at a concentration range of $10-200 \mu \mathrm{g} / \mathrm{mL}$ for $24 \mathrm{~h}$. The investigation was performed by MTT test (MTT) and NR uptake cytotoxicity assay (NR). 


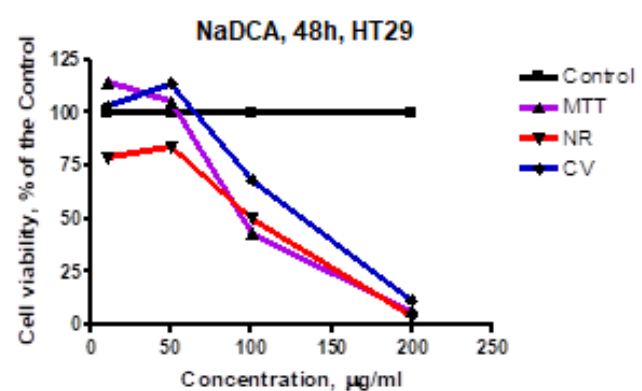

(a)

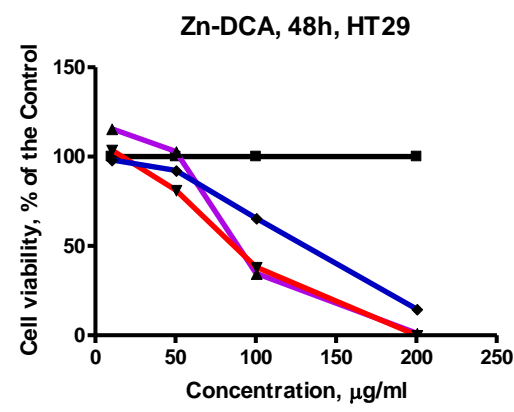

(b)

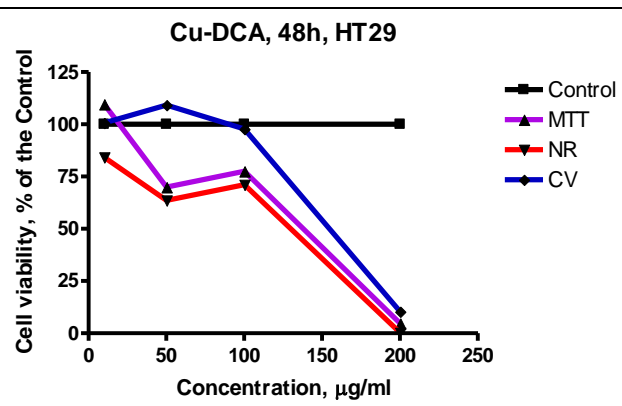

(c)

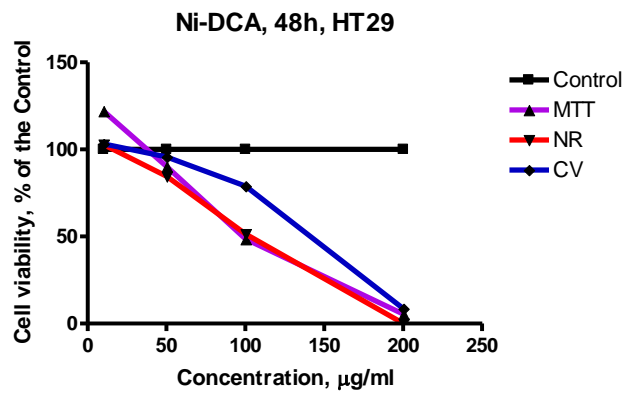

(d)

Figure 5.

Influence of NaDCA (a), ZnDCA (b), CuDCA (c) and NiDCA (d) on viability and proliferation of cultured HT29 human colorectal cells

The compounds are applied at a concentration range of $10-200 \mu \mathrm{g} / \mathrm{mL}$ for $48 \mathrm{~h}$. The investigation was performed by MTT test, NR uptake cytotoxicity assay and crystal violet staining (CV).

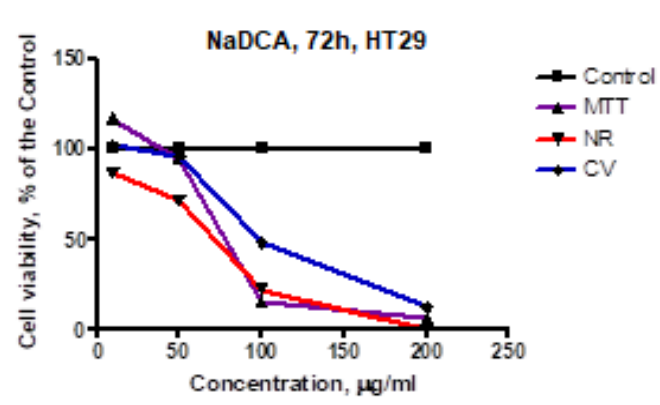

(a)

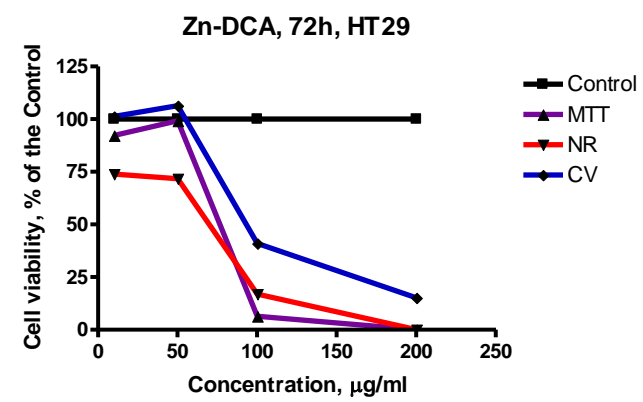

(b)

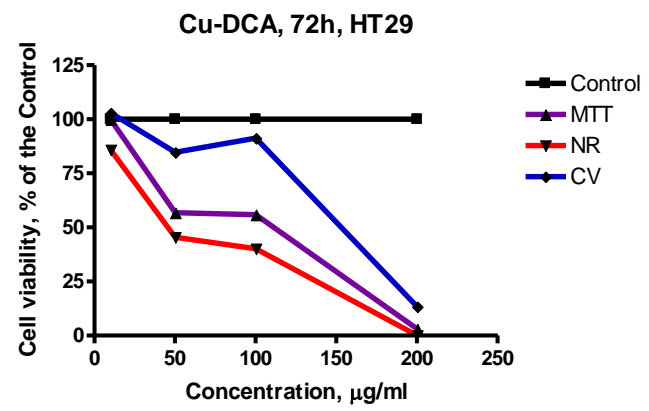

(c)

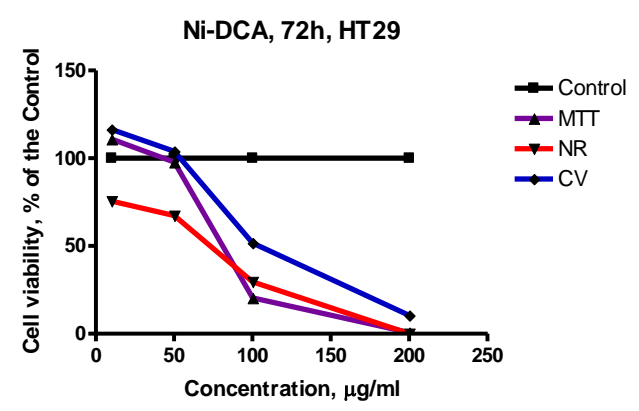

(d)

Figure 6.

Influence of NaDCA (a), ZnDCA (b), CuDCA (c) and NiDCA (d) on viability and proliferation of cultured HT29 human colorectal cells

The compounds are applied at a concentration range of $10-200 \mu \mathrm{g} / \mathrm{mL}$ for $72 \mathrm{~h}$. The investigation was performed by MTT test, NR uptake cytotoxicity assay and CV staining. 


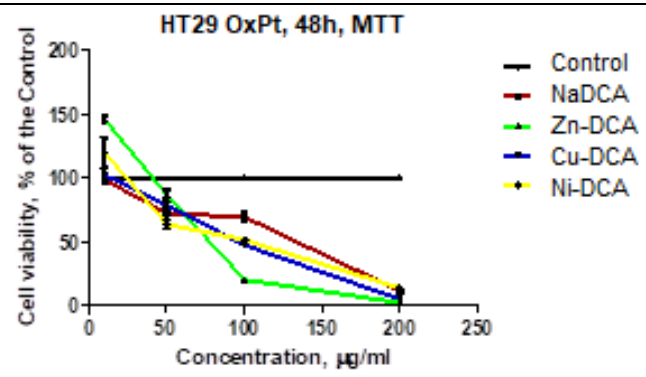

(a)

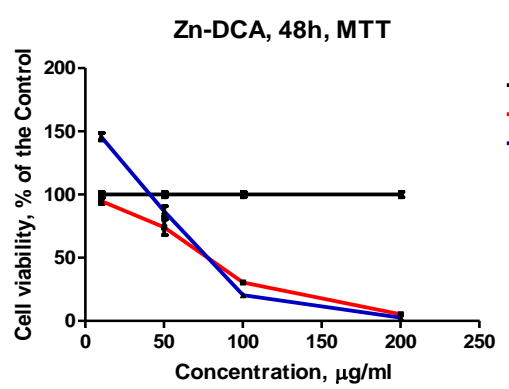

(b)

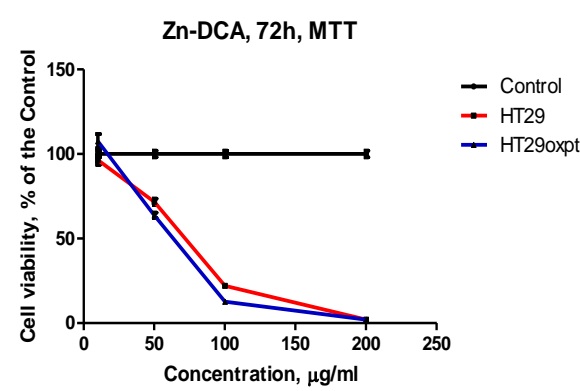

(c)

Figure 7.

Influence of NaDCA and its metal complexes on viability and proliferation of human colorectal carcinoma cells resistant to Oxaliplatin (the cell line HT29-OxPt) (a); Effect of ZnDCA on viability and proliferation of HT29 and HT29-OxPt human colorectal carcinoma cells

The compounds are applied at a concentration range of $10-200 \mu \mathrm{g} / \mathrm{mL}$ for after $48 \mathrm{~h}(\mathrm{a}, \mathrm{b})$ and $72 \mathrm{~h}(\mathrm{c})$. The investigation was performed by MTT test.

$\mathrm{CC}_{50}(\mu \mathrm{M})$ and $\mathrm{CC}_{90}(\mu \mathrm{M})$ were calculated from "concentration-response" curves (Figures 4, 5, 6 and 7) and presented in Table IV. Based on their cytotoxic activity $\left(\mathrm{CC}_{50}, \mu \mathrm{M}\right)$, the examined compounds are graded in hierarchical orders (Table V), showing that the metal complexes were pronounced cytotoxic agents as compared to sodium deoxycholate. The resistant
HT29-OxPt cells demonstrated the highest sensitivity to the cytotoxic effect of $\mathrm{ZnDCA}$.

The $\mathrm{CC}_{50}$ of oxaliplatin $(65.4 \mu \mathrm{M})$ and epirubicin $(45.4 \mu \mathrm{M})$ determined by the MTT test (after 72 hours of treatment) was found to be lower than the $\mathrm{CC}_{50}$ (determined at the same conditions) of NaDCA (321.4 $\mu \mathrm{M})$ and its complexes with zinc (II) $(138.2 \mu \mathrm{M})$, copper (II) (122.6 $\mu \mathrm{M})$ and nickel (II) $(125.2 \mu \mathrm{M})$.

Table IV

Cytotoxic activity $\left(\mathrm{CC}_{50}, \mu \mathrm{M}\right.$ and $\left.\mathrm{CC}_{90}, \mu \mathrm{M}\right)$ of $\mathrm{NaDCA}$ and its metal complexes on cultured human colorectal

\begin{tabular}{|c|c|c|c|c|c|c|}
\hline \multirow[t]{3}{*}{ Cell line } & \multirow[t]{3}{*}{ Method } & \multirow{3}{*}{$\begin{array}{c}\text { Treatment } \\
\text { interval } \\
\text { (hours) }\end{array}$} & \multicolumn{4}{|c|}{$\begin{array}{c}\mathbf{C C}_{50} \\
\left(\mathbf{C C}_{90}\right)\end{array}$} \\
\hline & & & \multicolumn{4}{|c|}{ Compound } \\
\hline & & & NaDCA & Zn-DCA & $\mathrm{Cu}-\mathrm{DCA}$ & Ni-DCA \\
\hline \multirow{9}{*}{ HT 29} & & 24 & $\begin{array}{c}310.4 \\
(506.3)\end{array}$ & $\begin{array}{c}130.1 \\
(221.7)\end{array}$ & $\begin{array}{c}159.7 \\
(-)\end{array}$ & $\begin{array}{c}138.3 \\
(-)\end{array}$ \\
\hline & MTT & 48 & $\begin{array}{c}340.0 \\
(490.7)\end{array}$ & $\begin{array}{c}142.4 \\
(207.7)\end{array}$ & $\begin{array}{c}150.1 \\
(210.8)\end{array}$ & $\begin{array}{c}122.0 \\
(194.4)\end{array}$ \\
\hline & & 72 & $\begin{array}{c}321.4 \\
(490.7)\end{array}$ & $\begin{array}{c}138.2 \\
(204.2)\end{array}$ & $\begin{array}{c}122.6 \\
(203.1)\end{array}$ & $\begin{array}{c}125.2 \\
(187.5)\end{array}$ \\
\hline & & 24 & $\begin{array}{c}362.0 \\
(-)\end{array}$ & $\begin{array}{c}140.2 \\
(213.5)\end{array}$ & $\begin{array}{c}159.6 \\
(-)\end{array}$ & $\begin{array}{c}133.9 \\
(-)\end{array}$ \\
\hline & NR & 48 & $\begin{array}{c}289.4 \\
(481.1)\end{array}$ & $\begin{array}{l}118.1 \\
(201.7)\end{array}$ & $\begin{array}{c}140.6 \\
(202.7)\end{array}$ & $\begin{array}{c}104.3 \\
(184.0)\end{array}$ \\
\hline & & 72 & $\begin{array}{c}244.6 \\
(457.1)\end{array}$ & $\begin{array}{c}104.8 \\
(199.3)\end{array}$ & $\begin{array}{c}207.3 \\
(192.7)\end{array}$ & $\begin{array}{c}90.3 \\
(181.7)\end{array}$ \\
\hline & & 24 & - & - & - & - \\
\hline & CV & 48 & $\begin{array}{c}336.8 \\
(-)\end{array}$ & $\begin{array}{c}144.5 \\
(-)\end{array}$ & $\begin{array}{c}169.0 \\
(-)\end{array}$ & $\begin{array}{c}143.9 \\
(200.8)\end{array}$ \\
\hline & & 72 & $\begin{array}{c}337.3 \\
(-)\end{array}$ & $\begin{array}{c}158.4 \\
(-)\end{array}$ & $\begin{array}{c}166.0 \\
(-)\end{array}$ & $\begin{array}{c}106.0 \\
(-)\end{array}$ \\
\hline
\end{tabular}


FARMACIA, 2021, Vol. 69, 3

\begin{tabular}{|c|c|c|c|c|c|c|}
\hline \multirow[t]{3}{*}{ Cell line } & \multirow[t]{3}{*}{ Method } & \multirow{3}{*}{$\begin{array}{c}\text { Treatment } \\
\text { interval } \\
\text { (hours) }\end{array}$} & \multicolumn{4}{|c|}{$\begin{array}{c}\mathbf{C C}_{50} \\
\left(\mathbf{C C}_{90}\right) \\
\end{array}$} \\
\hline & & & \multicolumn{4}{|c|}{ Compound } \\
\hline & & & NaDCA & Zn-DCA & Cu-DCA & Ni-DCA \\
\hline & & 24 & - & $\begin{array}{c}170.4 \\
(-)\end{array}$ & $\begin{array}{c}208.7 \\
(-)\end{array}$ & - \\
\hline HT29-OxPt & MTT & 48 & $\begin{array}{c}341.8 \\
(-)\end{array}$ & $\begin{array}{c}86.5 \\
(-)\end{array}$ & $\begin{array}{c}119.4 \\
(206.6)\end{array}$ & $\begin{array}{c}105.0 \\
(-)\end{array}$ \\
\hline & & 72 & $\begin{array}{c}191.1 \\
(-) \\
\end{array}$ & $\begin{array}{c}93.0 \\
(200.1) \\
\end{array}$ & $\begin{array}{c}124.8 \\
(212.2) \\
\end{array}$ & $\begin{array}{c}130.6 \\
(-) \\
\end{array}$ \\
\hline
\end{tabular}

$\mathrm{CC}_{50}$ and $\mathrm{CC}_{90}$ (in brackets) concentrations $(\mu \mathrm{M})$, in which the percentage of viable cells decrease by $50 \%$, respectively $90 \%$, compare to the control; symbol (-) refers to cases where cell survival remains $>50 \%$ or $>10 \%$, respectively, at all tested concentrations $(10-200 \mu \mathrm{g} / \mathrm{mL})$

Table V

Hierarchical orders of NaDCA and its metal complexes, reflecting the effect of the compounds on viability and proliferation of the treated cells

\begin{tabular}{rcc}
\hline Cell line & Treatment interval (hours) & Hierarchical order \\
\hline \multirow{3}{*}{ HT29 } & 24 & Zn-DCA $>$ Ni-DCA $>$ Cu-DCA $>$ NaDCA \\
& 48 & Ni-DCA $>$ Zn-DCA $>$ Cu-DCA $>$ NaDCA \\
& 72 & Cu-DCA $>$ Ni-DCA $>$ Zn-DCA $>$ NaDCA \\
\hline \multirow{3}{*}{ HT29-OxPt } & 24 & Zn-DCA $>$ Cu-DCA $>$ (Ni-DCA; NaDCA) \\
& 48 & Zn-DCA $>$ Ni-DCA $>$ Cu-DCA $>$ NaDCA \\
& 72 & Zn-DCA $>$ Cu-DCA $>$ Ni-DCA $>$ NaDCA \\
\hline
\end{tabular}

The compounds investigated are ordered in descending order according to their ability to reduce the survival of the treated cells, based on $\mathrm{CC}_{50}(\mu \mathrm{M})$ determined by MTT test

Various cytopathological changes and apoptotic cell death were observed after double staining with acridine orange and propidium iodide in HT29 cells cultured in the presence of $\mathrm{NaDCA}$ and its metal complexes (Figure 8). Figure 8a (HT29 Control) reveals a monolayer of vital cells with similar morphology and presence of multiple mitoses. After treatment with $100 \mu \mathrm{g} / \mathrm{mL} \mathrm{NaDCA}$ for $48 \mathrm{~h}$ (Figure $8 \mathrm{~b}$ ), a partially distorted monolayer of homogeneous in shape and size cells with a nuclear-distorted nuclear cytoplasmic index, pronounced nuclear polymorphism and fine grain chromatin, single cells in mitosis could be observed. Cells with impaired membrane integrity were predominant and were visibly permeable to small amounts of propidium iodide. By increasing the concentration of NaDCA to $200 \mu \mathrm{g} / \mathrm{mL}$ (Figure 8c), the HT29 cell monolayer was reduced to $80 \%$ relatively to the control and was represented by non-vital cells with late apoptosis signs: reduced size, scarce cytoplasm and heterogeneous pyknogenic chromatin nucleus, cell membrane with impaired integrity and presence on the cells surface of multiple apoptotic bodies. 100 $\mu \mathrm{g} / \mathrm{mL}$ CuDCA treatment (Figure $8 \mathrm{~d}$ ) produced a disturbed cell monolayer, represented by rosette clustered enlarged, but vital cells with enlarged nucleus, large granulated chromatin and nucleolus. There were also small groups of diminished non-vital cells and apoptotic bodies on the surface of the cell membrane. When CuDCA was applied at a concentration of $200 \mu \mathrm{g} / \mathrm{mL}$ (Figure 8e), rosette clusters of cells with signs of late apoptosis can be observed. The cytoplasm was reduced, nucleus was with pyknotic chromatin, cell membranes were permeable to propidium iodide. When treatment was performed with $100 \mu \mathrm{g} / \mathrm{mL}$ NiDCA (Figure 8f), the HT29 cell monolayer was reduced by $50 \%$ in comparison to the control, and predominantly represented by vital cells with a core-shifted nucleotidecytoplasmic index. A small number of cells have a permeability of the cell membrane, and disaggregated cell fragments were seen in the spaces between the preserved cell groups. By increasing the concentration of NiDCA to $100 \mu \mathrm{g} / \mathrm{mL}$ (Figure $8 \mathrm{~g}$ ), the cell monolayer was represented by small groups of non-viral cells with ballooned cytoplasm, deleted cytoplasmic and nuclear morphology. There were multiple extracellular fragments, the presence of which, along with the lack of signs of apoptosis, suggests necrotic cell death. After $100 \mu \mathrm{g} / \mathrm{mL}$ ZnDCA treatment (Figure 8h) groups of 15 - 20 non-vital cells can be observed, most of them with reduced size to untreated cells, with impaired membrane integrity and homogeneous cytoplasm without organelles. Intact nuclei in part of the cells with a coarse-grained chromatin and nucleolus appeared. When ZnDCA was applied at $200 \mu \mathrm{g} / \mathrm{mL}$ (Figure 8i), all HT29 cells became non-vital, with reduced size in comparison to the untreated cells, and completely deleted nuclear cytoplasmic morphology. $\mathrm{NaDCA}$ and its metal complexes were proved by the method of Comet Assay to induce single- and doublestranded DNA breaks (Table VI). Comet assay data showed that with increasing concentrations of the tested compounds the percentage of comets, i.e. cells with damaged DNA increased. The most prominent was the genotoxicity of all compounds at $200 \mu \mathrm{g} / \mathrm{mL}$, with ZnDCA and NiDCA (at $200 \mu \mathrm{g} / \mathrm{mL}$ ) demonstrating the highest genotoxic activity on the cells. 

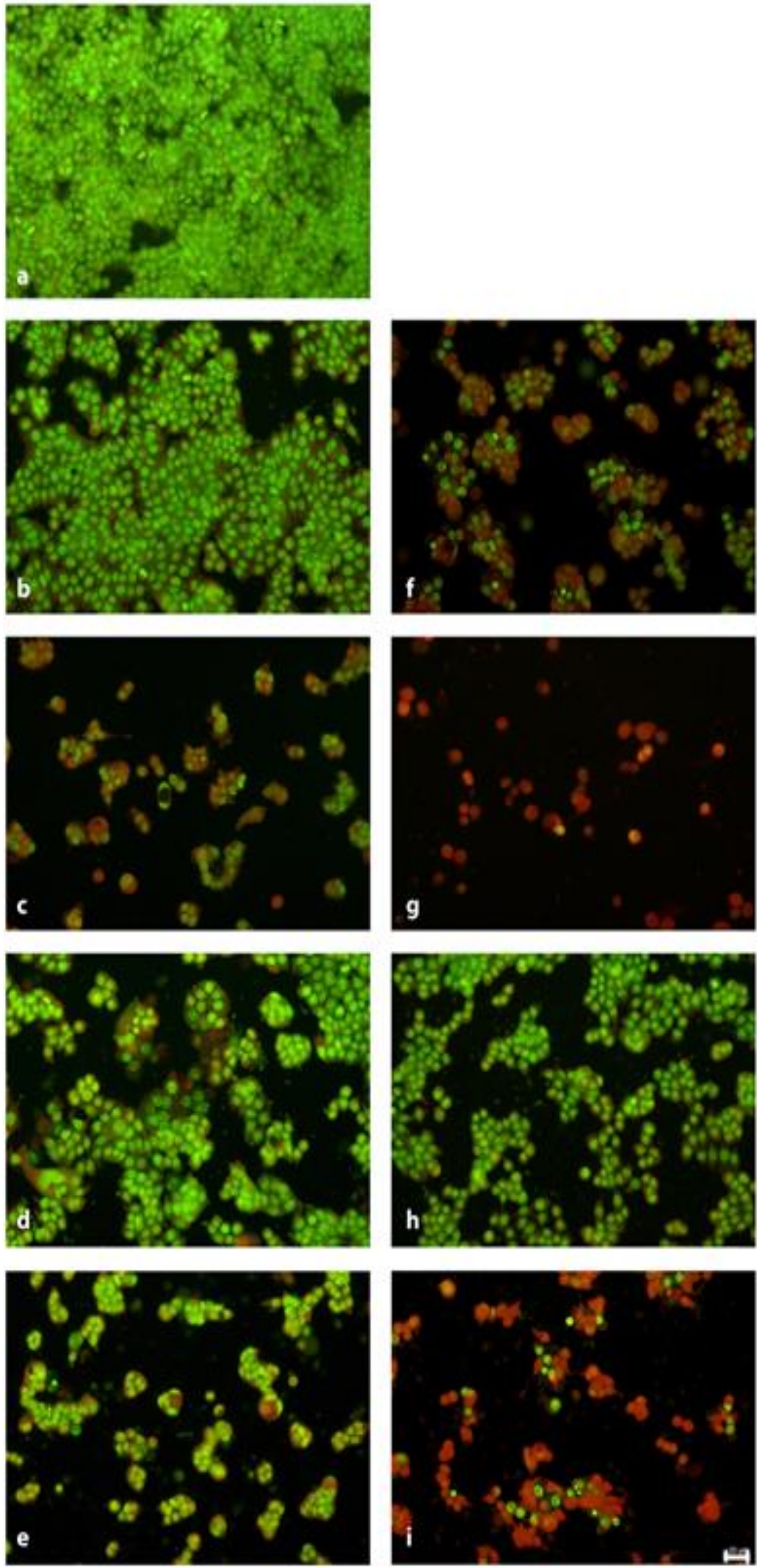

Figure 8.

Cytopathological changes in HT29 human colorectal cancer cells after treatment for $48 \mathrm{~h}$ with NaDCA and its metal complexes (scale bar $=20 \mu \mathrm{m}$ ): HT29 Control (a); $100 \mu \mathrm{g} / \mathrm{mL} \mathrm{NaDCA} \mathrm{(b);200 \mu g/mL} \mathrm{NaDCA} \mathrm{(c);} 100$ $\mu \mathrm{g} / \mathrm{mL}$ CuDCA (d); $200 \mu \mathrm{g} / \mathrm{mL}$ CuDCA (e); $100 \mu \mathrm{g} / \mathrm{mL}$ NiDCA (f); $200 \mu \mathrm{g} / \mathrm{mL} \mathrm{NiDCA} \mathrm{(g);} 100 \mu \mathrm{g} / \mathrm{mL}$ ZnDCA (h); $200 \mu \mathrm{g} / \mathrm{mL}$ NiDCA (i) 
Genotoxicity of NaDCA and its metal complexes in HT29 human colorectal cancer cells

\begin{tabular}{cccc}
\hline Compounds & Concentration $(\boldsymbol{\mu g} / \mathbf{m L})$ & Cell viability*, \% of the Control & Comets**, \% of the Control \\
\hline \multirow{2}{*}{ NaDCA } & 100 & $15.3 \pm 3.1$ & $40.0^{*}$ \\
& 200 & $5.9 \pm 1.3$ & 66.7 \\
ZnDCA & 100 & $6.4 \pm 0.5$ & 47.0 \\
& 200 & $0.0 \pm 0.0$ & 80.0 \\
CuDCA & 100 & $55.8 \pm 0.8$ & 47.0 \\
& 200 & $3.1 \pm 0.1$ & 53.3 \\
NiDCA & 100 & $20.4 \pm 3.8$ & 60.0 \\
& 200 & $0.74 \pm 0.02$ & 73.3 \\
\hline
\end{tabular}

*Cell viability was examined by MTT test, **Alkaline variant of Comet assay was performed to evaluate the genotoxic effect of the compounds. HT29 cells were cultured in the presence of NaDCA and its metal complexes for 72 hours. The results are expressed as mean \pm standard error of the mean of four repetitions in each group. The differences of the individual groups relative to the control were determined by single-factor dispersion analysis (ANOVA), followed by the Dunnet test $\left({ }^{*} P<0.05 ; * * P<0.01\right)$.

Cellular morphology was assessed by FACS analysis after staining of cells with propidium iodide (Table VII). FACS results showed that all tested compounds induced pathological changes in HT29 cellular morphology (compare to the \% of cells with normal size and granularity for all probes). The portion of cells with normal morphology gradually decreased with the incubation of the cells with the compounds reciprocally to the applied concentrations. The most prominent was the effect of the compounds on the population of the cells detected with big size and high granularity. The percentage of cells with these pathological changes in the morphology was gradually increasing being the most pronounced for NaDCA, $\mathrm{ZnDCA}$ and CuDCA. FACS analysis was further used to study the type of cell damage. The cells were incubated

with the tested substances and after that were submitted to FACS with Annexin V Apoptosis/Necrosis detection kit. Results are shown in Table VII. Cells were distributed in four groups depending on their FACS detected Annexin V characteristics: live cells, cells in early and late apoptosis and cells in necrosis. All tested compounds exerted cytotoxicity which was demonstrated in the decreasing number of live cells in all treated probes. FACS Annexin V data showed that all tested compounds induced late apoptosis and necrosis in the cells regardless concentration. This prompts apoptosis is one of the mechanisms of cell death induction in HT29 cells and requires further studies to elucidate this mechanism in details. The reduction in cellular viability was with $50 \%$ in comparison to the control cells.

Table VII

Ability of NaDCA and its metal complexes to induce changes in cellular morphology and apoptosis of HT29

\begin{tabular}{|c|c|c|c|c|c|c|c|c|c|}
\hline & Control & $\begin{array}{c}\text { Na- } \\
\text { DCA- } \\
100\end{array}$ & $\begin{array}{c}\text { Na- } \\
\text { DCA- } \\
200\end{array}$ & $\begin{array}{c}\text { Zn- } \\
\text { DCA- } \\
100\end{array}$ & $\begin{array}{c}\text { Zn- } \\
\text { DCA- } \\
200 \\
\end{array}$ & $\begin{array}{c}\text { Cu- } \\
\text { DCA- } \\
100\end{array}$ & $\begin{array}{c}\mathrm{Cu}- \\
\text { DCA- } \\
200 \\
\end{array}$ & $\begin{array}{c}\text { Ni- } \\
\text { DCA- } \\
100\end{array}$ & $\begin{array}{c}\text { Ni- } \\
\text { DCA- } \\
200 \\
\end{array}$ \\
\hline $\begin{array}{l}\text { Normal size/normal } \\
\text { granularity }\end{array}$ & 53.20 & 45.6 & 32.00 & 39.10 & 32.40 & 52.00 & 38.70 & 48.60 & 41.30 \\
\hline $\begin{array}{l}\text { Normal size/high } \\
\text { granularity }\end{array}$ & 1.29 & 2.88 & 2.17 & 2.17 & 2.99 & 1.65 & 1.71 & 1.17 & 0.87 \\
\hline $\begin{array}{l}\text { Big size/high } \\
\text { granularity }\end{array}$ & 35.20 & 44.00 & 62.00 & 53.10 & 63.00 & 32.10 & 53.50 & 38.20 & 49.70 \\
\hline $\begin{array}{l}\text { Big size/normal } \\
\text { granularity }\end{array}$ & 10.40 & 7.48 & 3.81 & 5.65 & 1.62 & 14.20 & 6.16 & 12.00 & 8.06 \\
\hline Live cells & 70.00 & 34.40 & 22.00 & 25.60 & 13.80 & 39.30 & 26.40 & 34.20 & 28.70 \\
\hline Early apoptosis & 11.90 & 1.47 & 0.81 & 0.92 & 0.14 & 1.00 & 1.67 & 0.97 & 1.04 \\
\hline Late apoptosis & 13.20 & 37.10 & 33.42 & 41.20 & 25.30 & 30.10 & 40.10 & 32.90 & 35.10 \\
\hline Necrosis & 5.99 & 27.00 & 43.70 & 32.30 & 60.80 & 29.60 & 31.80 & 32.00 & 35.20 \\
\hline
\end{tabular}

The long-term cytotoxic effect of the compounds tested was studied by 3D colony-forming method. The obtained experimental data (Table VIII) indicate that applied for 14 days and 48 days at a concentration of $200 \mu \mathrm{g} / \mathrm{mL}, \mathrm{NaDCA}, \mathrm{ZnDCA}$ and CuDCA completely inhibited 3D growth of HT29 cells in a semisolid medium. Undoubtedly, these data are of interest, as they suggest that the cytotoxic/cytostatic effect of the compounds persists over time. In addition, threedimensional cell colonies hold number of advantages over traditional monolayer (2D) cell cultures, as they more adequately represent biology and behaviour of tumour cells. 
Table VIII

Influence of NaDCA and its metal complexes on 3D colony-forming ability of HT29 human colorectal cancer

\begin{tabular}{lcccc}
\hline Compounds & $\begin{array}{c}\text { Concentration, } \\
\boldsymbol{\mu} \mathbf{g} / \mathbf{m L}\end{array}$ & \multicolumn{3}{c}{ HT29 } \\
\cline { 3 - 5 } & & $\mathbf{6}$ Colonies, \% of the Control \\
\cline { 3 - 5 } Control & & $100 \pm 0.66$ & $100 \pm 1.87$ & $\mathbf{4 8 ~ d a y}$ \\
& 10 & $100 \pm 0.29$ & $96.11 \pm 0.00$ & $83.49 \pm 1.38^{* * *}$ \\
NaDCA & 50 & $28.57 \pm 0.58^{* * *}$ & $75.68 \pm 2.84^{* * *}$ & $18.90 \pm 0.58^{* * *}$ \\
& 100 & $42.86 \pm 0.64^{* * *}$ & $37.24 \pm 0.85^{* * *}$ & $1.57 \pm 0.25^{* * *}$ \\
& 200 & $28.57 \pm 0.58^{* * *}$ & $0.00 \pm 0.00^{* * *}$ & $0.00 \pm 0.00^{* * *}$ \\
& 10 & $42.86 \pm 0.96^{* * *}$ & $90.10 \pm 1.25^{* * *}$ & $42.53 \pm 0.48^{* * *}$ \\
CuDCA & 50 & $71.43 \pm 0.64^{* * *}$ & $40.84 \pm 1.26^{* * *}$ & $39.38 \pm 0.48^{* * *}$ \\
& 100 & $50.00 \pm 0.25^{* * *}$ & $19.22 \pm 0.82^{* * *}$ & $6.30 \pm 0.71^{* * *}$ \\
& 200 & $14.28 \pm 0.29^{* * *}$ & $0.00 \pm 0.00^{* * *}$ & $0.00 \pm 0.00^{* * *}$ \\
& 10 & $57.14 \pm 0.71^{* * *}$ & $96.11 \pm 0.00$ & $45.68 \pm 1.03^{* * *}$ \\
ZnDCA & 50 & $50.00 \pm 0.48^{* * *}$ & $90.10 \pm 1.25^{* *}$ & $33.08 \pm 0.75^{* * *}$ \\
& 100 & $21.43 \pm 0.48^{* * *}$ & $33.64 \pm 1.78^{* * *}$ & $14.18 \pm 0.95^{* * *}$ \\
& 200 & $28.58 \pm 0.41^{* * *}$ & $0.00 \pm 0.00^{* * *}$ & $0.00 \pm 0.00^{* * * *}$ \\
& 10 & $85.71 \pm 0.41^{* * *}$ & $102.11 \pm 1.25$ & $51.98 \pm 1.49^{* * *}$ \\
NiDCA & 50 & $57.14 \pm 0.71^{* * *}$ & $60.07 \pm 1.89^{* * *}$ & $40.96 \pm 1.19^{* * *}$ \\
& 100 & $50.00 \pm 0.63^{* * *}$ & $60.07 \pm 1.44^{* * *}$ & $36.23 \pm 0.48^{* * *}$ \\
& 200 & $71.43 \pm 0.5^{* * *}$ & $81.69 \pm 0.71^{* * *}$ & $26.78 \pm 0.75^{* * *}$ \\
\hline
\end{tabular}

$3 \mathrm{D}$ cell colonies were observed by an inverted light microscope (Carl Zeiss, Jena, Germany) and counted in 4 - 5 independent visual fields at $6^{\text {th }}, 14^{\text {th }}$ and $48^{\text {th }}$ day. The experimental data are presented as mean \pm standard error of the mean of four repetitions in each group. The differences of the individual groups relative to the control were determined by single-factor dispersion analysis (ANOVA), followed by the Dunnet post hoq test $(* * * P<0.01)$.

In the recent years, potential anticancer properties of NaDCA have gained increasing attention because of at least two reasons: (i) NaDCA has been reported to inhibit proliferation and to induce apoptosis in cells obtained from human colon cancer $[48,49]$ and gastric carcinoma [50]; (ii) coupling with bile acid (such as deoxycholic acid) moieties has been suggested to be a promising strategy for liver-targeted drug delivery due to the presence of bile acid receptors on hepatocytes [51]. Deoxycholic acid modified conjugates have been developed and proposed as suitable novel carriers for anticancer drugs including epirubicin and paclitaxel [52, 53]. Transport and apoptosis induction was reported in hepatocellular carcinoma cells as a result of treatment with camptothecin-deoxycholic acid derivate [54].

According to the literature available, in this study we report for the first time the ability of deoxycholic acid sodium salt and its metal $\mathrm{Zn}$ (II), $\mathrm{Cu}$ (II) and $\mathrm{Ni}$ (II) complexes to decrease viability and 2D/3D growth of human HT29 and HT29-OxPt colorectal cells.

\section{Conclusions}

In conclusion, three new complexes of $\mathrm{Cu}$ (II), $\mathrm{Ni}$ (II) and $\mathrm{Zn}(\mathrm{II})$ with deoxycholate ligand were synthesized and characterized on the basis of elemental analysis, FTIR, UV-Vis, thermal analysis, conductivity and magnetic measurements. Biological investigations have demonstrated that these complexes manifest more pronounced cytotoxic activity both in human colorectal cancer cells and in resistant to oxaliplatin malignant cells as compared to the free ligand. Our findings represent a goal for a promising experimental treatment of colorectal cancer with metal complexes with deoxycholate as ligand and deserve further investigations.

\section{Acknowledgement}

This study was supported by (Project DFNP-17-89 by the Bulgarian Ministry of Education and Science under the National Research Programme "Young scientists and postdoctoral students" approved by DCM \# 577 / 17.08.2018; National Science Fund, Bulgarian Ministry of Education and Science (Grant №ДКОСТ 01-10 from 22.10.2018); COST Action CA16119 "CellFit" and a bilateral project between Bulgarian Academy of Sciences and Romanian Academy.

\section{Conflict of interest}

The authors declare no conflict of interest.

\section{References}

1. D'Archivio AA, Galanti L, Gavuzzo E, Giglio E, Mazza F, Calcium Ion Binding to Bile Salts. Langmuir, 1997; 13: 3090-3095.

2. Feroci G, Fazio G, Fini A, Zuman P, Interaction Between $\mathrm{Cu}^{2+}$ Ions and Cholic Acid Derivatives followed by Polarography. J Pharm Sci., 1995; 84(1): 119-125.

3. Sun Y, Yang ZL, Zhang L, Zhou NF, Weng SF, $\mathrm{Wu} \mathrm{JG}$, The interaction of $\mathrm{Co}^{2+}$ ions and sodium deoxycholate micelles. J Mol Struct., 2003; 655(2): 321-330. 
FARMACIA, 2021, Vol. 69, 3

4. Popadyuka II, Markov AV, Morozova EA, Babich VO, Salomatina OV, Logashenko EB, Zenkova MA, Tolstikova TG, Salakhutdinov NF, Synthesis and evaluation of antitumor, anti-inflammatory and analgesic activity of novel deoxycholic acid derivatives bearing aryl- or hetarylsulfanyl moieties at the $\mathrm{C}-3$ position, Steroids, 2017; 127: 1-12.

5. Hofmann AF, The continuing importance of bile acids in liver and intestinal disease. Arch Intern Med., 1999; 159: 2647-2658.

6. Kollerov VV, Lobastova TG, Monti D, Deshcherevskaya NO, Ferrandi EE, Fronza G, Riva S, Donova MV, Deoxycholic acid transformations catalyzed by selected filamentous Fungi. Steroids, 2016; 107: 20-29.

7. Varshosaz J, Sadri F, Rostami M, Mirian M, Taymouri $\mathrm{S}$, Synthesis of pectin-deoxycholic acid conjugate for targeted delivery of anticancer drugs in hepatocellular carcinoma. Int J Biol Macromol., 2019; 139: 665-677.

8. He XL, Xing Y, Gu XZ, Xiao JX, Wang YY, Yi Z, Qiu WW, The synthesis and antitumor activity of lithocholic acid and its derivatives. Steroids, 2017; 125: 54-60.

9. Wang P, She G, Yang Y, Li Q, Zhang H, Liu J, Cao $\mathrm{Y}, \mathrm{Xu} \mathrm{X}$, Lei H, Synthesis and biological evaluation of new ligustrazine derivatives as anti-tumor agents. Molecules, 2012; 17: 4972-4985.

10. Chen G, Yang L, Zhang H, Tucker IG, Fawcett JP, Effect of ketocholate derivatives on methotrexate uptake in Caco-2 cell monolayers. Int J Pharm., 2012; 433: 89-93.

11. Kramer W, Wess G, Enhsen A, Bock K, Falk E, Hoffman A, Neckermann G, Gantz D, Schulz S, Nickau L, Petzinger E, Turley S, Dietschyc JM, Bile-acid-derived HMG-CoA reductase inhibitors. Biochim Biophys Acta, 1994; 1227: 137-154.

12. Kramer W, Wess G, Schubert G, Bickel M, Girbig F, Gutjahr U, Kowalewski S, Baringhaus KH, Enhsen A, Glombik H, Mullner S, Neckermann G, Schulzll S, Petzinger E, Liver-specific drug targeting by coupling to bile acids. J Biol Chem., 1992; 267: 18598-18604.

13. Maeda M, Takasuka M, Suga T, Sasaki T, New antitumor platinum(II) complexes with both lipophilicity and water miscibility. Jap J Cancer Res., 1990; 81: 567-569.

14. Criado JJ, Herrera MC, Palomero MF, Medarde M, Rodriguez E, Marin JJG, Synthesis and characterization of a new bile acids and platinum(II) copmplex with cytostatic activity. J Lipid Res., 1997; 38: 1022-1032.

15. Marin JJG, Palomero MF, Herrera MC, Macias RIR, Criado JJ, Serrano MA, In Vitro Cytostatic Activity and DNA-interaction of the New Liver Organotropic Complex Chloro-Bis-Cholylglycinate-Platinum (II). Anticancer Res., 1998; 18: 1641-1647.

16. Marin JJG, Macias RIR, Criado JJ, Bueno A, Monte MJ, Serrano MA, DNA interaction and cytostatic activity of the new liver organotropic complex of cisplatin with glycocholic acid: BAMET-R2. Int $J$ Cancer, 1998; 78: 346-352.

17. Larena MG, Martinez-Diez MC, Monte MJ, Dominguez MF, Pascual MJ, Marin JJ, Liver organotropism and biotransformation of a novel platinum-ursodeoxycholate derivative, Bamet-UD2, with enhanced antitumour activity. J Drug Target, 2001; 9(3): 185-200.
18. Huang L, Liu R, Li J, Liang X, Lan Q, Shi X, Pan L, Chen H, Ma Z, Synthesis, characterization, anti-tumor activity, photo-luminescence and $\mathrm{BHb} / \mathrm{HHb} / \mathrm{Hsp} 90$ molecular docking of zinc(II) hydroxyl-terpyridine complexes. J Inorg Biochem., 2019; 201: 110790: 1-12.

19. Marzano C, Pellei M, Tisato F, Santini C, Copper complexes as anticancer agents (Review). Anti-Cancer Agents Med Chem., 2009; 9(2): 185-211.

20. Liu RX, Wang CY, Wu YS, Luo RY, Jiang XH, Tang MT, Liu YC, Chen ZF, Liang H, The copper(II) complexes of new anthrahydrazone ligands: In vitro and in vivo antitumor activity and structure-activity relationship. J Inorg Biochem., 2020; 212: 111208: 1-13.

21. Khan HY, Ansari MO, Shadab GGHA, Tabassum S, Arjmand F, Evaluation of cytotoxic activity and genotoxicity of structurally well characterized potent cobalt(II) phen-based antitumor drug entities: An in vitro and in vivo approach, Bioorg Chem., 2019; 88: 102963: 1-12.

22. Tamminen J, Kolehmainen E, Bile Acids as Building Blocks of Supramolecular Hosts. Molecules, 2001; 6(1): 21-46.

23. Kritchevsky D, Nair PP, The Bile Acids: Chemistry, Physiology, and Metabolism; Eds., Plenum, New York, 1971, Vol. 1.

24. Sun Y, Yang ZL, Zhang L, Hu TD, Soloway RD, Weng SF, Wu JG, The interaction of $\mathrm{Cu}^{2+}$ ions and NaDC micelles. Spectrochim Acta Part A, 2002; 58(9): 1489-1498.

25. Huang WD, Hu TD, Peng Q, Soloway RD, Weng SF, Wu JG, EXAFS and FTIR studies on the binding of deoxycholic acid with copper and zinc ions. Biospectroscopy, 1995; 1(4): 291-296.

26. Culita DC, Patron L, Marinescu G, Constantinescu T, Alexandrova R, Rashkova G, Coordination compounds with cholate anion as ligand. II. Coordination compounds of $\mathrm{Cu}(\mathrm{II}), \mathrm{Co}(\mathrm{II}), \mathrm{Ni}(\mathrm{II})$ and $\mathrm{Zn}(\mathrm{II})$. Rev Roum Chim., 2005; 50(9-10): 745-749.

27. Culita DC, Patron L, Carp O, Stanica N, Constantinescu $\mathrm{T}$, Coordination compounds with cholate anion as ligand. I. Coordination compounds of lanthanides $(\operatorname{Ln}(\mathrm{III})=\mathrm{La}-\mathrm{Er})$. Rev Roum Chim., 2004; 49: 735-740.

28. Dyakova L, Culita DC, Marinescu G, Alexandrov M, Kalfin R, Patron L, Alexandrova R, Metal ( $\mathrm{Zn}, \mathrm{Cu}$, $\mathrm{Ni}$ ) complexes of ursodeoxycholic acid as putative anticancer agents. Biotechnol Biotechnol Equip., 2014; 28(3): 543-551.

29. Jensen NF, Stenvang J, Beck MK, Hanáková B, Belling KC, Do KN, Viuff B, Nygård SB, Gupta R, Rasmussen MH, Tarpgaard LS, Hansen TP, Budinská E, Pfeiffer P, Bosman F, Tejpar S, Roth A, Delorenzi M, Andersen CL, Establishment and Characterization of Models of Chemotherapy Resistance in Colorectal Cancer: Towards a Predictive Signature of Chemoresistance. Mol Oncol., 2015; 9(6): 1169-1185.

30. Mosmann T, Rapid colorimetric assay for cellular growth and survival: application to proliferation and cytotoxicity assays. J Immunol Methods, 1983; 65(12): 55-63.

31. Borenfreund E, Puerner JA, Toxicity determined in vitro by morphological alterations and neutral red absorption. J Toxicol Lett., 1985; 24: 119-124. 
32. Saotome K, Morita H, Umeda M, Cytotoxicity test with simplified crystal violet staining method using microtitre plates and its application to injection drugs. Toxicol In Vitro, 1989; 3(4): 317-321.

33. Abdel Wahab SI, Abdul AB, Alzubairi AS, Mohamed Elhassan M, Mohan S, In vitro ultramorphological assessment of apoptosis induced by zerumbone on (HeLa). J Biomed Biotechnol., 2009; 2009: 769568: 1-11.

34. Olive PL, Cell proliferation as a requirement for development of the contact effect in Chinese hamster V79 spheroids. Radiat Res., 1989; 117: 79-92.

35. Georgieva M, Efremov T, Alexandrova R, Miloshev $\mathrm{G}$, Comet assay discriminates levels of chromatin compaction, Compt Rend Acad Bulg Sci., 2009; 62(4): 479-484.

36. Nakamoto K, Infrared and Raman Spectra of Inorganic and Coordination Compounds, fourth ed., John Wiley $\&$ Sons, New York, 1986; 231-232.

37. Shaheen F, Ali S, Rosario S, Shah NA, Synthesis and structural elucidation of bioactive triorganotin(IV) derivatives of sodium deoxycholate. J Coord Chem., 2014; 67: 1851-1861.

38. Lever ABP, Inorganic Electronic Spectroscopy, Elsevier, London, 1968; 333-357.

39. Kanta Das L, Gómez-García CJ, Ghosh A, Influence of the central metal ion in controlling the selfassembly and magnetic properties of $2 \mathrm{D}$ coordination polymers derived from $[(\mathrm{NiL}) 2 \mathrm{M}] 2+$ nodes $(\mathrm{M}=\mathrm{Ni}$, $\mathrm{Zn}$ and $\mathrm{Cd})(\mathrm{H} 2 \mathrm{~L}=$ salen-type di-Schiff base $)$ and dicyanamide spacers. Dalton Trans., 2015; 44: 12921302.

40. Cotton FA, Wilkinson G, Murillo CA, Bochmann M, Advanced Inorganic Chemistry, $6^{\text {th }}$ Edition, John Wiley \& Sons, 1999.

41. Ali I, Wani WA, Saleem K, Empirical Formulae to Molecular Structures of Metal Complexes by Molar Conductance. Synth React Inorg Met Chem., 2013; 43: 1162-1170.

42. Geary WJ, The Use of Conductivity Measurements in Organic Solvents for the Characterisation of Coordination Compounds. Coord Chem Rev., 1971; 7: 81-122.

43. Collins AR, The comet assay: a heavenly method. Mutagenesis, 2015; 30(1): 1-4.

44. Krasteva N, Keremidarska-Markova M, HristovaPanusheva K, Andreeva T, Speranza G, Wang D, Draganova-Filipova M, Miloshev G, Georgieva M, Aminated Graphene Oxide as a Potential New Therapy for Colorectal Cancer. Oxid Med Cell Longev., 2019; 2019: 3738980: 1-16.

45. Alexandrova R, Zhivkova T, Alexandrov M, Miloshev G, Georgieva M, Pantcheva I, Mitewa M, Cytostatic and cytotoxic properties of monensic acid and its biometal(II) complexes against human tumor / nontumor cell lines. Cent Eur J Chem., 2012; 10(5): 14641474.

46. Dyakova L, Culita DC, Zhivkova T, Georgieva M, Spasov R, Miloshev G, Kalfin R, Marinescu G, Patron $\mathrm{L}$, Alexandrova R, Effect of meloxicam and its metal [Zn(II), $\mathrm{Cu}(\mathrm{II}), \mathrm{Co}(\mathrm{II}), \mathrm{Ni}(\mathrm{II})]$ complexes on viability and/or proliferation of human non-small cell lung cancer cells. Int J Pharm Res., 2020; 12(3): 1479-1490.

47. Dyakova L, Influence of non-steroidal anti-inflammatory agents, bile acids and their metal complexes on viability and proliferation of tumor cells. $\mathrm{PhD}$ thesis. Institute of Neurobiology - Bulgarian Academy of Sciences, Sofia, Bulgaria, 2019.

48. Yui S, Kanamoto R, Saeki T, Deoxycholic acid can induce apoptosis in the human colon cancer cell line HCT116 in the absence of Bax. Nutr Cancer, 2008; 60(1): 91-96.

49. Barrasa JI, Olmo N, Perez-Ramos P, Santiago-Gomez A, Lecona E, Turnay J, Lizarbe MA, Deoxycholic and chenodeoxycholic bile acids induce apoptosis via oxidative stress in human colon adenocarcinoma cells. Apoptosis, 2011; 16: 1054-1067.

50. Yang HB, Song W, Cheng MD, Fan HF, Gu X, Qiao Y, Lu X, Yu RH, Chen LY, Deoxycholic acid inhibits the growth of BGC-823 gastric carcinoma cells via a p53 mediated pathway. Mol Med Rep., 2015; 11(4): 2749-2754.

51. Xiao L, Xu J, Weng Q, Zhou L, Wang M, Liu M, Li $\mathrm{Q}$, Mechanism of a Novel Camptothecin-Deoxycholic Acid Derivate Induced Apoptosis Against Human Liver Cancer HepG2 Cells and Human Colon Cancer HCT116 Cells. Recent Pat Anticancer Drug Discov., 2019; 14(4): 370-382.

52. Gao F, Li L, Zhang H, Yang W, Chen H, Zhou J, Zhou Z, Wang Y, Cai Y, Li X, Liu L, Deoxycholic acid modified-carboxymethylcurdlan conjugate as a novel carrier of epirubicin: in vitro and in vivo studies. Int J Pharm., 2010; 392(1-2): 254-260.

53. Li J, Huo M, Wang J, Zhou J, Mohammad JM, Zhang Y, Zhu Q, Waddad AY, Zhang Q, Redoxsensitive micelles self-assembled from amphiphilic hyaluronic acid-deoxycholic acid conjugates for targeted intracellular delivery of paclitaxel. Biomaterials, 2012; 33: 2310-2320.

54. Li Q, Liu T, Li Y, Luo S, Zhu Q, Zhang L, Zhao T, Transport and killing mechanism of a novel camptothecindeoxycholic acid derivate on hepatocellular carcinoma cells. J Drug Target, 2014; 22(6): 543-552. 